\title{
The Dimensions of Marketing Mix
}

\author{
Khalid Sudian Al Badi ${ }^{1, *}$ \\ ${ }^{1}$ Ministry of Health, Head of Internal Audit Department, Faculty Member, Al Buraimi College University, Sultanate \\ of Oman \\ *Correspondence: Ministry of Health, Head of Internal Audit Department, Faculty Member, Al Buraimi College \\ University, Sultanate of Oman. E-mail: k.vip.10@hotmail.com
}

Received: August 28, 2014

Accepted: September 22, $2014 \quad$ Online Published: January 12, 2015

doi:10.5430/mos.v2n1p136

URL: http://dx.doi.org/10.5430/mos.v2n1p136

\begin{abstract}
This paper discusses the 4 'P's of marketing mix, which comprise: product, price, place and promotion, and the connection with integrated marketing. Marketing managers use the Marketing Mix model in an attempt to generate the optimal response in the target market by blending these four variables in an optimal way. The marketing mix is flexible and can be adjusted on a frequent basis to meet the changing needs of the target group and the other dynamics of the marketing environment. It is important to understand that the Marketing Mix principles are controllable variables. The dimensions of marketing mix go a long way towards the product management, customer data base, segmenting, targeting and positioning, which will be the main topics of this paper. In addition, it provides some examples (companies such as McDonalds and Air Arabia) to emphasis this concept.
\end{abstract}

Keywords: marketing mix; 4Ps; product management; product life cycle; segmentation

\section{Introduction}

The marketing mix is probably the most famous marketing term. Kinnear and Bernheerd (2002) define it as the use and specification of the 4Ps (price, product, place and promotion) to describe the strategic position of a product in the marketplace. Macmillan and Baron (2004) define the marketing mix as "those activities that show similarities to the overall process of marketing, requiring the combination of individual elements". Also, Czinkota (2000) gives the following definition of the marketing mix: "A complex of tangible and intangible elements to distinguish it in the market place". According to the analysis of marketing Mix, it is about how to create, communicate and deliver value to the consumer in order to make profit. In this context, create is related to the product management, which is very vital to any profit and non-profit organization, starting from the idea (in terms of consumer wants, needs and demands) up to the final product or service. The communication in this context relates to the customer data base that develops awareness of the need of a product from their perspective and obtaining value, which is the core concept of the customer satisfaction. In the product management concept, all products, both old and new, are prone to the phases of a life cycle. A Product Life Cycle (PLC) has four main successive phases, which are: the Introduction Phase, the Growth Phase, the Maturity Phase and finally, the Decline Phase. In accordance with each phase, behavior responds to change and this is apparent in the volume of sales, product related costs, channels of distribution, competitors, volume of advertising, price, promotions and more dependence on quantity from one phase to another. "The product life cycle theory draws an analogy with the life cycle of human beings, in that every product in a market is mortal. In the world of biology, each stage in the cycles is fixed, with one stage following on from another in both an invariable and irreversible order. In the marketing world, however, neither of these circumstances is typical, the length of different stages of the life cycle tending to differ from product to product" (Dhalla and Yuspeh, 1976).

The concept of PLC is the emergence process of a new product on the market. This emergence goes through many changes due to internal and external circumstances. The main issue for any organization is to deal with the right segment in the market in order to create a product or a service that fits with that specific segment; from this point we can notice the interaction between the product management and the segmentation. Market Segmentation provides the databases needed for decision makers and strategic planner in marketing process. Segmentation is the key point in how the management dealing with the market structure and customer identification. Market intelligence is one of the marketing tools which assist modeling best strategies in order to improve product and customer management, 
communication, distribution channels and pricing schemes. The main objective of segmentation is to identify and classify customers based on their needs and wants, who possess the similar characteristics to one another, so the efforts of marketing can be focused and directed to them. In the same context, the product or service needed, consumer behavior, or the other factors can be a guide for segmentation. Through the segmentation process, the organization develops its marketing plans to be driven by customer's needs, and gain a competitive advantage.

\section{What is 4Ps?}

Marketing Mix based on four elements;

1-product

This word express about what organization introduce to those audience who are dealing with it. It may be a services, goods, or utilities, the customer accept to have a complete production not only just a tangible goods or services but also others things which it connected to it. For example the essential product for Oman National Transport Company is the service of transportations, but the complete service here is connected by exactly time, and other elements such as transportations lines inside Oman and provide a nice and safety vehicles.

So the development of production strategy requires making sure that the product which is introduced to the customer satisfy him. It include also the right choose for the brand, packing, grantee services etc.

2- place

Place strategy involves what the channels distributions have been used to deliver the products to the customers on time, and the way of store, chose the sellers. In general, there is no organization has all strategy of place and market, therefore each organization focuses on strategic elements which is have rather than others. For example Al Ain Mineral Water in UAE using the strategy of distributions it is products by transporting to the final customer rather than retailers sellers.

3- price

Price is the amount of money that intended customers willing to pay to get a product or a kind of service. Price is the most flexibility element on Marketing Mix, it can change or be changed rapidly in short term more than others Ps. There are some prices which is changed daily like shares, gold prices, currencies prices etc. To change price there are strategic or technics reasons, which I will discuss it later on this seminar paper.

Pricing decisions supposed to make a profit margin and the right or probable price with take care about competitors price. Pricing include not only the price list but also, discount, financing, and other options such as leasing.

\section{Pricing Methods}

\section{1- cost based}

Costs effect on the price which is organization setting, and most costs tend in raising constantly. The organization may face the this raising in some way. For example by keeping the price of product same with decreasing in product volume, reducing price by use low cost materials, or increasing the price but in the same time modify product to satisfy customers.

\section{2- demand based}

The relationship between price and demand is controlled by the low of demand. So when demand is strong prices go up. When it is weak, the price goes down.

The low of demand involves that customers normally buy more of items from the same product if it price goes down.

This way based on marketing researching to assess the needful of that product and which price should be on each period of product line.

\section{3- competition based}

Consider the price of the other competitors, and may not consider about the changing on cost or demand unless these changing effect on competitors prices.

There are two pictures of pricing based on competition:

1-Price leadership, expresses about those organization which have the large share in the market and good trade 
market ( a famous brand) and have the respecting from other competitors, for example Ideal Company which is manufacturing refrigerators, other small companies price its refrigerators on base of Ideal price.

2-Competitive bidding, here two or more organization competition to win a bidding.

Some applications of how price instruments contribute to marketing mix functions

3.1 McDonald's: "think global, act local"

As we know there is a wide popularity of McDonald's over the world. But how McDonald's price its product over the world, and how it effect on other marketing mix element. McDonalds, use internationalisation and globalisation elements according to various fast food markets. Using the effect of strategically and tactical models. McDonald's success to being able to adapt to a specific environment. This is very good example which appear the pricing strategy localisation rather than globalisation. For each country, there is a specific pricing policy is used with take care about the product, place and promotion. For example the price of Big Mac in Australia is $0.87 \mathrm{uk}$ pond but in Brazil is $1.52 \mathrm{uk}$ pond, this differentiation on price refer to the product( which quality or kind of product use in each country), place (channels of distributions), promotions ( how much advs. about Big Mac). British Food Journal.

\subsection{Air Arabia}

Air Arabia is the first and only low-fares airline in the Middle East and North Africa region, with a vision to be one of the world's leading budget airlines in terms of profit margin, innovation, reputation and operational excellence. http://www.airarabia.com.

This airline comes with new prices for its travels, and it had a wide popularity especially on Gulf Countries. The fare from Sharja ( UAE) to Mumbi is 1035 AED ( $=300$ USA Dollars), and the fare from Sharja (UAE) to Colombo is 580 $\operatorname{AED}(=150$ USA Dollars). This is without taxes and surcharges which is not exceed 100 USA Dollar, so these prices effect on product ( which is here services of travelling, for example no meal in the plane), Distributions ( use those directions which have low income people), and promotion (it doesn't spent a lot in their advertisements)

\section{Promotion}

It is the communication process between the customer and the product or service, it is what the promotions try to tell target customer about the product, and it's the way to make customer aware about the product.

Promotion includes all the weapons in the marketing armory - advertising, selling, sales promotions, Public Relations, etc. While the other three P's have lost much of their meanings in today's markets, Promotion has become the most important $P$ to focus on. (Dibb, Simkin, Pride, and Ferrel, 1994).

\section{In Which Way May Price Instruments Contribute to Marketing Mix Functions?}

As we mentioned the price expresses about the value of goods or services, and the Price Planning term expresses about the systemic way which the organization flows it in order to decide how to price their products. Considers a number of aspects of pricing, including the relationship between price and supply and demand, pricing objectives, factors affecting pricing decisions and aspects of pricing policy and pricing method.

"The price mechanism is the dominant force in resource allocation, income distribution and size and composition of output" (Backman, 1965).

\section{Why is the Product Life Cycle (PLC) Concept Important for Marketing Managers?}

The importance of PLC comes from these main points:

- PLC is an effective and important tool for strategic planning; it is both necessary and important for mangers to plan the appropriate cycle that their product will pass through. In doing so, they will be able to consider alternative strategies in addition to establishing marketing strategies which have an effect on the demand of consumers in the market whilst considering all the circumstances.

- Managers focus on the PLC concept as typical behaviour that controls sales movement and profit and their directions. The PLC has been used as a base to revise a marketing strategy in order to develop the processes of a new product, which has replaced an old product after its decline. Also, it helps managers to provide an appropriate marketing mix over different stages of a PLC so as to face all predicted circumstances. Therefore, the PLC concept enhances the clarity of product behavior and can assist to provide the right strategies for each 
stage.

- The significance of the PLC is due to the benefits it provides for the product managers to comprehend and describe the changes in a marketing share rate, profitability and the intensity of competitors.

- The PLC concept focuses on determining the position of each product in a cycle in order to choose the correct and most effective marketing mix, which contributes to the increase in sales and profit.

- According to the PLC, basic suggestions and strategies are finalized so as to control the final stage of the cycle, that is, the decline phase, which is considered the most sensitive. New marketing samples and multiple strategies are adopted in order to overcome this stage and control it, for example, revitalization or product deletion from the market so that there are no effects on the reputation of the organization.

- A PLC represents the framework which forms the life of a product as a readable and comprehensible image thereby giving the product clarity and comprehension. This is due to the unique strategy of each stage.

As mentioned above, marketing managers can implement some strategies across each stage of a PLC and these are discussed below.

1. Strategies used in an Introduction Stage -

Here, marketing mangers use pioneer advantage strategy, and the product strategy in this stage focuses on introducing the product pricing which would be high to cover the expenses. For example, the Al Mraai company, a dairy food products producer. The company has used the pioneer advantage strategy to market its mixed fruit label in its first introduction of the new product and because of the existing good reputation of the company, customers were satisfied in spite of high pricing. There are other factors to be considered in this stage, such as, intensive promotion and elective distributions.

\section{Strategies used in a Growth Stage -}

This stage marks the period of acceptance of a product in the market, sales revenue and profit rising. In this stage, managers expand the channels of distribution and promotion to build the market share. However, prices seem to be the same as in the Introduction stage or may decrease smoothly because of competition or demand factors. Marketing mangers here develop the quality of a product and add more features to it. Profitability is ignored in the short term as the plan for high revenue in the long-term takes precedence.

\section{Strategies used in the Maturity stage -}

After increasing sales and profit in the previous stage, these will continue to increase until the maturity stage is reached. In this stage, managers try to up profit as much as they can, while at the same time continuing to increase their market share of the product. However, the main objective here will be more short-term than long-term because the life cycle of the product will enter the Decline stage. For example, the Etisalat company, which is located in the UAE. A specializer in the telecommunications sector, it promotes its rechargeable phone cards (WASEL) make offers and decreasing its price in order to encourage customers to buy them in response to its competitor, du.

\section{Strategies used in the Decline stage -}

Sales decline is the feature of this stage. Sales reduce sharply because of the significant increase made in technological change, consumer tastes, competitors and both internal and external factors. These all lead to excess capacity, unnecessarily low prices and the gradual erosion of profits as the sales and profits decrease rapidly. The company is left with no choice but to withdraw the product from the market.

The marketing objective of this stage is limited to reducing expenses, using the brand as much as possible and implementing alternative solutions and strategies to control the phase when the product has reached the point of completion. This is for the purpose of delaying the process of developing a new product or establishment. Where the product is present, the organization will lose field competition generally.

When the organization is trying to withdraw the product, many decisions have to be made. If the product is well-known and extensive, strong distribution, the organization may sell it on to another organization. However, liquidation is forced upon them.

By this stage, the organization may have decided to withdraw the product from the market after exhausting all other solutions and begin developing a new product and in turn a new life. 


\section{How the Segmentation Helps Organizations? (hotels business)}

The mass-marketing approach, in which a single marketing program is used to attract all customers, is rarely appropriate especially these days. Moving away from mass marketing towards a market-segmentation approach is a common way of dealing with diverse customer needs (Dibb, Simkin, ,Pride, and Ferrel, 1994).

Market segmentation is a key decision area for business undertaking marketing and strategic planning (McDonald 1995). Put simply, a business is more likely to be successful if it designs a specific marketing mix for a group of customers with similar needs. This assumption applies to businesses of all types, from confectionery manufacturers that promote their product ranges on the basis of the occasion on which they are consumed, to hotel groups that organize their property portfolios into sites geared to business or tourist occupancy.

In the hotels market, the services and marketing programs must be carefully designed to appeal to the needs of different customer groups. It is important for hotel marketers to identify customer needs and use this understanding to develop suitable marketing mixes. They should know that the needs of different customers vary. Business people who travels all over the world staying nights in the hotels will not have the same requirements as an new married couple who wish to spend their honey moon in wonderful environment where everybody recognize them and serve them. Different services standard and activities program needed to meet these diverse needs. To achieve customer satisfaction, improve their marketing effectiveness and enhance their ability to capitalize on market opportunities hotels should identify and single out customer groups at which to direct some or all of their marketing activity. In other words, they should adopt a market segmentation strategy.

The various business benefits to a segmentation approach:

- Customer analysis: Segmentation encourages businesses more precisely to define customer needs, expectations, and characteristics, Managers improve their understanding of how, why, and what influences customer buying. Being more closely in touch with customers increases their responsiveness to changing requirements, allowing more finely tuned marketing programmers.

- Competitor analysis: analysis of the competitive environment is an essential part of the segmentation process. Businesses applying a segmentation approach must make targeting decisions about the attractiveness of particular segments. They must decide on how to position products within these segments and consider the nature of competitive advantage. Informed decisions on these matters can be taken only following careful competitor analysis.

- Resources allocation: The financial and other resources that marketers have at their disposal are finite. It is rarely realistic to target an entire market. Segmentation helps businesses allocate their resources effectively, by selecting the most attractive parts of the market on which to focus.

- Strengths and weaknesses: Through the customer and competitor analysis, segmentation encourages, marketers to take a realistic view of company strengths and weaknesses. This permits a more balanced appraisal of marketing opportunities.

- Marketing planning: Segmentation allows businesses to gear their planning towards the particular requirements of different customer groups. Different plans can be developed for each of the target segments. This allows marketers to be more responsive to the varying requirements of customers.

\section{Which Variables to Use for Hotels Business Segmentation?}

In the segmentation research, the challenge is to focus and search for the same pattern of consumer behavior and other factors in a specific segment. The relevant data about any segment markets are vital to this process. However, there are many factors that can be used as tools in order to understand the segmentation, the most common types of factors are using:

- Customer based variables

- $\quad$ Product/service based variables

Customer based variables, from its name, uses customer-driven strategy. In this context, we can include some characteristics such as demographic information and psychographic information. In the other hand, product/services related variables discovers the reaction of people and how to utilize a product, for instance, when the marketers using the brand loyalty, consumption patterns, quantity, or how the people react toward a new product and its price, or location of it, etc. 


\section{Conclusion}

The concept of a Product Life Cycle does not apply to all types of commodities. Indeed, all goods have certain advantageous specifications that distinguish them from other commodities. Consequently, the PLC may lead to incorrect decisions. And the PLC concept is of great importance where the facilitation of product conduct and behaviour across different stages of the life cycle are concerned. However, without the concept, it would be difficult to explain the behaviour of a product and, therefore, difficult to report objectives and marketing strategies.

Generally, application of the PLC concept contributes to facilitating product understanding, the role of decision-making and the development of marketing strategies and other alternatives. Price is one of the four major elements of the marketing mix. Pricing is an important strategic issue because it is related to product positioning. Furthermore, pricing affects other marketing mix elements such as product, place (channel decisions), and promotion. While there is no single recipe to determine pricing, this seminal paper tries to summarize the price methods and their effect on Marketing Mix.

\section{References}

A. Blake, C. Rother, M. Brown, P. Perez, \& P. Torr. (2004). Interactive Image Segmentation Using an Adaptive GMMRF Model. Proc. European Conf. Computer Vision, 428-441.

Aaker, D.A. (1996). Measuring brand equity across products and markets. California Management Review, 38(3), 102-20. http://dx.doi.org/10.2307/41165845s

Ambler, T. (2003). Marketing and the Bottom Line (2nd ed.). FT Prentice Hall, London.

Bonoma, T.V., \& Clark, B.C. (1988). Marketing Performance Assessment. Harvard Business School Press, Boston, MA.

Boulding, W., Staeling, R., Ehret, M., \& Johnston, W.J. (2005). A Customer Relationship Management Roadmap: What Is Known, Potential Pitfalls, and Where to Go. Journal of Marketing, 69(October), 155-166. http://dx.doi.org/10.1509/jmkg.2005.69.4.155

Brodie, R.J., Coviello, N.E., Brookes, R.W., \& Little, V. (1997). Towards a Paradigm Shift in Marketing? An Examination of Current Marketing Practices. Journal of Marketing Management, 13(5), 383-406. http://dx.doi.org/10.1080/0267257X.1997.9964481

Christopher, M., Payne, A., \& Ballantyne, D. (1991). Relationship Marketing. Oxford etc.: Butterworth-Heinemann.

Constantinides, E. (2006). The Marketing Mix Revisited: Towards the 21st Century Marketing. Journal of Marketing Management, 22, 407-438. http://dx.doi.org/10.1362/026725706776861190

Coviello, N., Brodie, R., Danaher, P., \& Johnston, W. (2002). How Firms Relate to Their Markets. An Empirical Examination of Contemporary Marketing Practices. Journal of Marketing, 66(July), 33-46. http://dx.doi.org/10.1509/jmkg.66.3.33.18500

Culliton, J.W. (1948). Management of Marketing Costs. Andover, MA: The Andover Press Ltd.

D'Esopo, M., \& Almquist, E. (2007). An approach to mastering the marketing mix. Business Strategy Series, 8(2), 122-31. http://dx.doi.org/10.1108/17515630710685186

Dhalla, N.K., \& Yaspeh, S. (1976). Forget the product life cycle concept. Harvard Business Review, JanuaryFebruary, 102-110.

Dibb, Simkin, Pride, \& Ferrell. (1994). Marketing Concepts and Strategies(2 ${ }^{\text {nd }}$ edition.). Houghton Mifflin Company, Hoofdstukken $7.8 \& 9$.

Donovan, R., \& Henley, N. (2010). Principles and Practice of Social Marketing: An International Perspective. Cambridge University Press, New York. http://dx.doi.org/10.1017/CBO9780511761751

Gabrielli, V., \& Balboni, B. (2010). SME practice towards integrated marketing communications. Marketing Intelligence and Planning, 28(3), 275-90. http://dx.doi.org/10.1108/02634501011041426

James H. Myers. (1996). Segmentation and positioning for Strategic Marketing Decisions American Making Association. Principles of Marketing: The Oxford Textbook of Marketing.

Kotler, P. Kotler. (2001). Marketing Management. Prentice-Hall, Englewood Cliffs.

Mc Carthy., \& William D. (1993). Basic Marketing. A Global Management Approach. In Richard briwin Inc. 
Stanto.W.J. (1987), Fundamental of Marketing, New York Mc Grawe Hill book company.

P. Arbelaez \& L. Cohen. (2008). Constrained Image Segmentation from Hierarchical Boundaries. Proc. IEEE Conf. Computer Vision and Pattern Recognition, 454-467.

S. Alpert, M. Galun, R. Basri, \& A. Brandt. (2007). Image Segmentation by Probabilistic Bottom-Up Aggregation and Cue Integration. Proc. IEEE Conf. Computer Vision and Pattern Recognition, June 2007.

S. Bagon, O. Boiman, \& M. Irani. (2008). “What Is a Good Image Segment? A Unified Approach to Segment Extraction," Proc. $10^{\text {th }}$ European Conf. Computer Vision, 30-44.

Wood, L. (1990). The end of the product life cycle? Educations says goodbye to an old friend. Journal of Marketing Management, 6(2), 145-15. http://dx.doi.org/10.1080/0267257X.1990.9964122

Y.Y. Boykov \& M.P. Jolly. (2001). Interactive Graph Cuts for Optimal Boundary and Region Segmentation of Objects in n-d Images. Proc. Eighth IEEE Int'l Conf. Computer Vision, 105-112. http://dx.doi.org/10.1109/ICCV.2001.937505 